\title{
MATHEMATICAL THINKING PROCESS IN GRAPH THEORY MATERIAL IN TERMS OF STUDENT LEARNING STYLES
}

\author{
Hetty Patmawati \\ Universitas Siliwangi, Tasikmalaya, Indonesia \\ hettypatmawati@unsil.ac.id
}

\begin{abstract}
This research is motivated by the lack of understanding students have in working on graph theory material problems due to differences in students thinking processes, and student learning styles when studying discrete mathematics, which requires different thinking with Boolean algebra material. Each student has a different way of thinking skills and learning style. This study uses descriptive qualitative methods so that this study has the objective to find out how the students' mathematical thinking processes in working on graph theory material problems and what obstacles are experienced by students in terms of their learning styles. The focus of research in this study, namely to analyze mathematical thinking processes on graph theory material in terms of student learning styles. The instruments in this study were researchers and also graph theory test questions that were used to view students' thought processes. The research subjects were 5 semester students, as many as 3 people with visual, auditory and kinesnetik learning styles. Then given the problem of graph theory as much as 2 questions, one question in the form of text and another in the form of images. The results show that students with visual learning styles tend to be included in students who have a conceptual thinking process, students with auditory learning styles tend to be included in students who have semi-conceptual thinking processes, while students with kinesthetic learning styles, including students who have computational thinking process. Barriers experienced by students include the lack of understanding of the basic concepts of graph theory and the trajectories and trajectories of Euler and Hamilton.
\end{abstract}

Keywords: mathematical thinking process, learning style, graph teory

\section{PROSES BERPIKIR MATEMATIS DALAM MATERI TEORI GRAF DITINJAU DARI GAYA BELAJAR MAHASISWA}

\begin{abstract}
ABSTRAK
Penelitian ini dilatarbelakangi oleh kurangnya pemahaman mahasiswa dalam mengerjakan soal materi teori graf karena perbedaan dalam proses berpikir mahasiswa, serta gaya belajar mahasiswa ketika kuliah matematika diskrit, yang memerlukan pemikiran berbeda dengan materi aljabar Boole. Setiap mahasiswa memiliki cara yang berbeda-beda dalam kemampuan berpikirnya serta gaya belajar. Penelitian ini menggunakan metode kualitatif deskriptif sehingga penelitian ini memiliki tujuan untuk mengetahui bagaimana proses berpikir matematis mahasiswa dalam mengerjakan soal materi teori graf dan hambatan apa saja yang dialami mahasiswa ditinjau dari gaya belajar nya. Fokus penelitian dalam penelitian ini, yaitu untuk menganalisis proses berpikir matematis pada materi teori graf ditinjau dari gaya belajar mahasiswa. Instrumen dalam penelitian ini adalah peneliti dan juga soal tes teori graf yang digunakan untuk melihat proses berpikir mahasiswa. Subjek penelitian adalah mahasiswa semester 5, sebanyak 3 orang dengan gaya belajar visual, auditorial dan kinesnetik. Kemudian diberikan soal teori graf sebanyak 2 soal, satu soal dalam bentuk teks dan satu lagi dalam bentuk gambar. Hasil penelitian menunjukkan mahasiswa dengan gaya belajar visual termasuk kedalam mahasiswa yang memiliki proses berpikir secara konseptual, mahasiswa dengan gaya belajar auditorial cenderung termasuk kedalam mahasiswa yang memiliki proses berpikir semi konseptual, sedangkan mahasiswa dengan gaya belajar kinestetis, termasuk kedalam mahasiswa yang memiliki proses berpikir komputasional. Hambatan-hambatan yang dialami mahasiswa diantaranya kurangnya pemahaman konsep dasar teori graf dan lintasan dan lintasan Euler dan Hamilton.
\end{abstract}

Kata Kunci: proses berpikir matematis, gaya belajar, teori graf

\begin{tabular}{|c|c|c|}
\hline Submitted & Accepted & Published \\
\hline 03 Januari 2020 & 15 September 2020 & 28 September 2020 \\
\hline
\end{tabular}

\begin{tabular}{|l|l|l|}
\hline Citation & $:$ & Patmawati, H. (2020). Mathematical Thinking Process In Graph Theory Material In Terms Of Student Learning Styles. \\
\hline
\end{tabular} Jurnal PAJAR (Pendidikan dan Pengajaran), 4(5), 1046-1049. DOI : http://dx.doi.org/10.33578/pjr.v4i5.8081.

\section{PENDAHULUAN}

Setiap mahasiswa memiliki cara yang berbeda-beda dalam memecahkan suatu masalah, hal ini memungkinkan terjadinya perbedaan

proses dalam berpikir. Banyak faktor yang mempengaruhi proses berpikir mahasiswa diantaranya kemampuan berpikir yang berbeda 
serta gaya belajar mahasiswa yang berbeda pula. Perbedaan gaya belajar dapat menyebabkan terjadinya perbedaan dalam pemahaman informasi yang diterima mahasiswa dan dapat menyebabkan terjadinya perbedaan dalam menyelesaikan masalah pada setiap individu mahasiswa.

Ada banyak cara untuk menjelaskan dan meng-ases gaya belajar, yakni cara-cara seseorang bersikap, merasakan, dan memproses informasi dalam suatu situasi belajar. Setiap mahasiswa mempunyai cara menyerap dan menyimpan informasi dan keterampilan, yang sangat berbeda dari individu ke individu, tanpa memperhatikan bagaimana deskripsi prosesnya.

Proses berpikir menurut Kuswana (2011) merupakan urutan kejadian mental yang terjadi secara alamiah atau terencana dan sistematis pada konteks ruang, waktu, dan media yang digunakan serta menghasilkan suatu perubahan terhadap objek yang dipengaruhi.

Dalam proses berpikir, mahasiswa akan menghubungkan antara pengertian yang satu dengan pengertian yang lainnya untuk mencapai kesimpulan dari permasalahan tersebut. Matematika mempunyai peran penting dalam membentuk pola pikir kreatif, kritis, sistematis, logis serta mempunyai kemampuan bekerja sama. Berpikir matematika timbul karena fikiran-fikiran manusia yang berhubungan dengan ide, proses, dan penalaran. Menurut Zuhri (dalam Yanti, Avissa dan Muhamad Syazali, 2016) proses berpikir dibedakan menjadi 3 jenis yaitu: Proses berpikir konseptual, yaitu proses berpikir peserta didik yang selalu menyelesaikan atau memecahkan masalah dengan menggunakan konsep yang dimiliki sesuai dengan pengalamannya selama ini. Proses berpikir semikonseptual, yaitu proses berpikir peserta didik yang cenderung dalam menyelesaikan masalah dengan menggunakan konsep tetapi kurang memahami konsep tersebut sehingga dalam menyelesaikan permasalahan dicampur dengan cara penyelesaian dengan menggunakan intuisi. Proses berpikir komputasional, yaitu proses berpikir yang dalam menyelesaikan masalah cenderung mengandalkan intuisi dan tidak menggunakan konsep.

Gaya belajar adalah cara dari seseorang dalam menyerap, mengatur dan mengolah informasi dalam belajar. Menurut DePorter dan Hernacki (2004), pada awal pengalaman belajar, salah satu langkah pertama yang mengenali visual, auditorial dan kunestetik. Visual belajar melalui apa yang mereka lihat, auditorial belajar melalui apa yang mereka dengar dan kinestetik belajar melalui gerak.

Dalam memahami materi teori graf, setiap mahasiswa terdapat perbedaan dari proses berpikir dalam menyelesaikan masalah yang ditemuinya. Juga gaya belajar setiap mahasiswa tentu berbedabeda, sehingga peneliti ingin mengetahui bagaimana proses berpikir matematis mahasiswa jika ditinjau dari gaya belajar, khusus nya pada materi teori graf.

\section{METODE PENELITIAN}

Jenis penelitian ini adalah penelitian kualitatif deskriptif. Dengan maksud untuk memahami fenomena tentang apa yang dialami oleh subjek penelitian. Dalam penelitian ini dimaksudnya untuk mendeksripsikan proses berpikir mahasiswa yang ditinjau dari gaya belajarnya. Sugiyono (2017) berpendapat, bahwa metode penelitian pada dasarnya cara ilmiah untuk mendapatkan data dengan tujuan dan kegunaan tertentu. Suatu metode penelitian mempunyai rancangan penelitian tertentu. Penelitian kualitatif berbeda dengan penelitain kuantitatif, dimana penelitian ini memandang kenyataan sebagai konstruksi sosial, individu atau kelompok, atau memberi makna kepada suatu kenyataan dengan mengkonstruksinya. Metode penelitian kualitatif adalah metode penelitian yang berlandaskan pada filsafat positivisme, digunakan untuk meneliti pada kondisi objek yang alamiah, dimana peneliti adalah sebagai instrumen kunci, teknik pengumpulan data dilakukan secara tringaluasi, analisis data bersifat induktif/kualitatif, dan hasil penelitian kualitatif lebih menekankan makna daripada generalisasi. 
Peneliti sendiri sebagai instrument utama, kemudian instrument selanjutnya yaitu soal tes teori graf, angket gaya belajar dan wawancara.

\section{HASIL DAN PEMBAHASAN}

Satu kelas mahasiswa mata kuliah matematika diskrit diberikan angket gaya belajar untuk menentukan subjek penelitian, mana yang termasuk kedalam kelompok mahasiswa yang memiliki gaya belajar visual, auditori dan kinestetis. Dari 34 orang mahasiswa terpilih 8 orang yang termasuk gaya belajar visual, 12 orang yang termasuk gaya belajar auditori dan 14 orang yang termasuk gaya belajar kinestetis.

Tabel 1. Data Hasil Penelitian

\begin{tabular}{|c|c|}
\hline $\begin{array}{c}\text { Tipe Gaya } \\
\text { Belajar }\end{array}$ & Subjek \\
\hline Visual & $\begin{array}{l}\text { S3, S7, S9, S10, S15, } \\
\text { S16, S17, S20 }\end{array}$ \\
\hline Auditori & $\begin{array}{l}\mathrm{S} 1, \mathrm{~S} 2, \mathrm{~S} 4, \mathrm{~S} 14, \mathrm{~S} 18, \\
\mathrm{~S} 19, \mathrm{~S} 21, \mathrm{~S} 22, \mathrm{~S} 23, \\
\mathrm{~S} 24, \mathrm{~S} 25, \mathrm{~S} 30\end{array}$ \\
\hline Kinestetik & $\begin{array}{l}\text { S5, S6, S8, S11, S12, } \\
\text { S13, S26, S27, S28, } \\
\text { S29, S31, S32, S33, } \\
\text { S34 }\end{array}$ \\
\hline
\end{tabular}

Dari data hasil penelitian diatas, terpilih 3 orang yang menjadi subjek penelitian diambil dari jumlah skor angket tertinggi, dengan masing2 kelompok gaya belajar 1 orang. S9 termasuk gaya belajar visual, S3 termasuk gaya belajar auditori dan S15 termasuk gaya belajar kinestetis. Setiap subjek penelitian diberikan soal materi teori graf sebanyak 2 soal dan diberikan pada waktu dan tempat yang berbeda. Pada saat subjek penelitian mengerjakan soal teori graf sambil di wawancara untuk mengetahui bagaimana proses berpikir matematisnya.

Tabel 2. Gaya Belajar

\begin{tabular}{ccc}
\hline Subjek & $\begin{array}{c}\text { Gaya } \\
\text { Belajar }\end{array}$ & Proses berpikir \\
\hline S9 & visual & konseptual \\
S3 & auditori & semi konseptual \\
S15 & kinestetis & komputasional \\
\hline
\end{tabular}

Dari ketiga subjek yang terpilih, menghasilkan bahwa S9 yang termasuk dengan konseptual, S3 yang termasuk dengan gaya belajar gaya belajar visual memiliki proses berpikir secara auditori memiliki proses berpikir semi konseptual dan S15 yang termasuk dengan gaya belajar 
kinestetis memiliki proses berpikir komputasional. Dengan hambatan setiap subjek hampir sama yaitu pemahaman konsep dasar teori graf dan lintasan Euler dan Hamilton.

Mahasiswa dengan gaya belajar visual cenderung memiliki proses berpikir konseptual karena dengan hanya melihat apa yang sudah dijelaskan oleh Peneliti, sehingga subjek memiliki proses berpikir nya secara konseptual, mahasiswa dengan gaya belajar auditorial cenderung memiliki proses berpikir semi konseptual dan mahasiswa dengan gaya belajar kinestetik cenderung memiliki proses berpikir secara komputasional.

\section{SIMPULAN DAN REKOMENDASI}

Berdasarkan hasil penelitian dan pembahasan dapat dideskripsikan sebagai berikut

1. Proses berpikir mahasiswa ditinjau dari gaya belajar visual pada materi teori graf cenderung konseptual, hal ini dikarenakan orang-orang dengan gaya visual memiliki ciri-ciri rapi dan teratur, perencana dan pengatur, teliti dan juga detail, membutuhkan pandangan secara menyeluruh, dan mengingat apa yang dilihat daripada yang didengar.

2. Proses berpikir mahasiswa ditinjau dari gaya belajar auditorial pada materi teori graf cenderung semi konseptual, hal ini dikarenakan orang-orang auditorial memiliki ciri-ciri dia berbicara sendiri saat mengerjakan soal, menggerakkan bibir mereka dan mengucapkan tulisan di lembar jawaban, merasa kesulitan untuk menulis, belajar dengan mendengarkan dan mengingat daripada apa yang dilihat.

3. Proses berpikir mahasiswa ditinjau dari gaya belajar kinestetik pada materi graf cenderung komputasional, hal ini dikarenakan orang-orang kinestetik memiliki ciri-ciri kemungkinan tulisan nya jelek, tidak dapat duduk diam dalam waktu lama, diakibatkan mengandalkan intuisi ingin melakukan sesuatu dan tidak menggunakan konsep.

\section{DAFTAR PUSTAKA}

De Porter \& Hernacki. (2002). Membiasakan Belajar Nyaman dan Menyenangkan. Jakarta. Kaifa

Kuswana. (2011). Taksonomi Berpikir. Bandung: Rosda Karya

Moleong, L. (2011). Metodologi Penelitian Kualitatif. Bandung: Remaja

Rosdakarya.

Sugiyono. (2017). Metode Penelitian Kuantitatif, Kualitatif dan $R \& B$. Bandung: Alphabeta.

Yanti, A., \& Syazali, M. (2016). Analisis Proses Berpikir Siswa dalam Memecahkan Masalah Berdasarkan Langkah-langkah Brainsford dan Stein ditinjau dari Adversity Quotient. Al-Jabar. Jurnal Pendidikan Matematika, 7(1 ), 63-74. 